\section{ScienceDirect}

Transportation Research Procedia 00 (2017) 000-000 $\overline{\text { Transportation }}$

Research

Procedia

www.elsevier.com/locate/procedia

World Conference on Transport Research - WCTR 2016 Shanghai. 10-15 July 2016

\title{
The tale of two (very different) cities - Mapping Urban Transport Oil Vulnerability of Brisbane and Hong Kong
}

\author{
Abraham Leung ${ }^{\mathrm{a}}$, Matthew Burke ${ }^{\mathrm{a}}$, Jenny Cui ${ }^{\mathrm{b}}$ \\ a Cities Research Centre, Griffith University, 170 Kessels Road, Nathan, Qld, 4111, AUSTRALIA \\ b School of Environment, Griffith University, 170 Kessels Road, Nathan, Qld, 4111, AUSTRALIA
}

\begin{abstract}
Peak Oil impacts have resulted in fluctuating and increasing oil prices in cities that are more dependent on imported oil. This issue has been receiving greater attention in Anglosphere land use and transport scholarship, especially in Australia where automobile use is high and public transport is comparatively inadequate. Higher transport cost could exacerbate transport disadvantage and cause social exclusion. However the geographical study of spatial variation of oil vulnerability within cities has not yet fully explored. Most international comparative urban studies on energy and/or oil use focus on aggregated municipal data only. This paper studies the comparative experience of spatial urban oil vulnerability in two very different Asia Pacific cities Brisbane and Hong Kong. Census and journey to work data are used to evaluate and map oil vulnerability based on prevailing vulnerability concepts of exposure, sensitivity with a specific focus on adaptive capacity. More advanced GIS methods are used to visualise and relate oil vulnerability indicators with various socio-demographic and transport characteristics for better understanding of this issue. Both cities' urban transport polices are also examined to explain the differences of transport and land use development and the resultant oil vulnerability. This study allows direct comparison of stark contrasts between one Asian and one western city in terms of urban form (dispersed vs. compact) and mode share (transit vs. car based). The policy, geographical and cultural context of both cities have influenced the type and extent of oil vulnerability. Hong Kong with a highly developed public transport network serves as a preferred urban transport model. However the risk of increasing oil prices also affects oilbased public transport such as buses and ferries and outer urban areas tend to be more affected. Despite the promise of electric vehicles reducing oil use, cities should still avoid being car dependent and oil vulnerable like Brisbane. The Hong Kong approach of strong transit-led transport policies and land-use matching with rail infrastructure investments that reduce oil consumption offers longer-term resilience.
\end{abstract}

(C) 2017 The Authors. Published by Elsevier B.V.

Peer-review under responsibility of WORLD CONFERENCE ON TRANSPORT RESEARCH SOCIETY.

Keywords: Peak Oil; oil vulnerability; vulnerability mapping; Asia Pacific cities; urban transport infrastrcuture; GIS

2214-241X @ 2017 The Authors. Published by Elsevier B.V.

Peer-review under responsibility of WORLD CONFERENCE ON TRANSPORT RESEARCH SOCIETY. 


\section{Introduction}

\subsection{Background}

Oil prices have been increasingly volatile since the 2000s. They reached extremely high levels in 2008 and 2011 2014 (Figure 1). Some have attributed this to the possibility of a peak in global oil production - so-called "peak oil" - which could not match consumption. Transport is one of the main users of oil given up to $93 \%$ of global transport energy use is sourced from oil; the transport sector is therefore highly reliant on an affordable and constant oil supply (International Energy Agency, 2009). Higher and unstable energy prices have challenged transport and land use planning. Many cities previously embraced widespread car ownership and use, in particular the New World cities of North America and Australia. At the same time, the Asia Pacific region is experiencing rapid industrialisation and urbanisation with drastic changes observed in the past few decades (Marcotullio, 2003). Increased wealth and economic development also bring exponential growth in transport needs. While municipal policy makers acknowledge the need for sustainable transport, policies to create viable public transport systems are in conflict with the local aspiration for western style private transport by means of car ownership (Barter et al., 2003). Table 1 shows the differing pace of motorisation: Australian cities are mature automobile cities with steady car-ownership growth over time. Asia Pacific cities are generally undergoing rapid motorisation, Japanese cities started earlier in terms of private motoring, then South East Asia and China is now "catching up" due to newly found wealth and strong car aspirations. An exception is found in certain compact cities such as Hong Kong, Shanghai and Singapore that have stringent car control measures and efficient mass public transport networks (Cullinane, 2003; Han and Seo, 2010). One notable feature of Hong Kong and Singapore is that they lack an automobile industry. Industrial policies that promote car growth may be attractive to policy makers due to perceived effects on industrial and economic development but at the cost of increased oil consumption, dependence on imported oil and environmental costs (Poudenx, 2008).

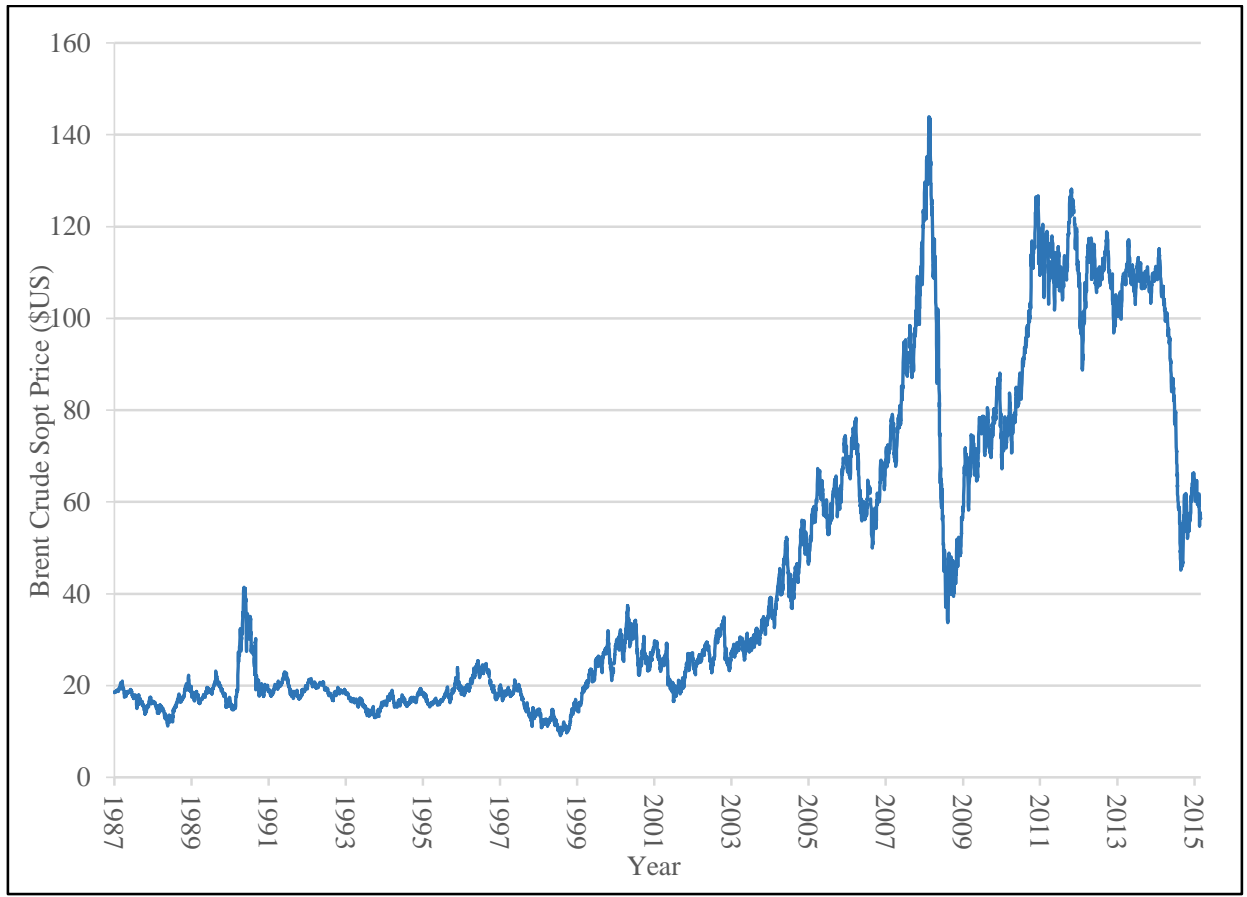

Figure 1. : Oil price fluctuations since 1987 (Source: US Energy Information Administration, 2015)

Table 1. Trends of Motorisation of Various Selected Asia Pacific cities (Adapted from Kenworthy and Laube, 2001; Kenworthy et al., 1999; UN Habitat, 2012) 


\begin{tabular}{|c|c|c|c|c|c|}
\hline Cities & $\begin{array}{l}1960 \\
\text { (passe } \\
\end{array}$ & 1980 & 2002 & $\begin{array}{c}2020 \\
\text { (projected) }\end{array}$ & $\begin{array}{c}\text { Rate of } \\
\text { Change } \\
1980-2020 \\
\text { (percentage) }\end{array}$ \\
\hline \multicolumn{6}{|l|}{ Australian } \\
\hline Perth & 239 & 475 & 658 & 694 & $46 \%$ \\
\hline Melbourne & 224 & 446 & 594 & 680 & $53 \%$ \\
\hline Brisbane & 192 & 458 & 596 & 610 & $33 \%$ \\
\hline Sydney & 214 & 399 & 516 & 550 & $38 \%$ \\
\hline \multicolumn{6}{|c|}{ Developed East Asian } \\
\hline Hong Kong & 11 & 42 & 59 & 70 & $65 \%$ \\
\hline Tokyo & 16 & 156 & 266 & 271 & $74 \%$ \\
\hline \multicolumn{6}{|c|}{ South-East Asian Developing } \\
\hline Bangkok & 14 & 71 & 324 & 389 & $447 \%$ \\
\hline \multicolumn{6}{|c|}{ Rapidly Developing Chinese } \\
\hline Beijing & (no data) & 9 & 80 & 177 & $1867 \%$ \\
\hline Shanghai & (no data) & 5 & 47 & 100 & $1900 \%$ \\
\hline
\end{tabular}

Gilbert and Perl (2012) suggests the following main issues on the continual use of oil may spark a "transport revolution" as seen in previous radical change in transport mode and energy choice:

1. Energy security and reducing risk of international conflict over energy resources ( $66 \%$ of the world's oil reserves are located in the Middle East.)

2. Climate change and carbon emissions

3. Sustainability (oil is finite and not renewable)

4. Pollution (airborne emissions from tailpipes, water pollution by oil runoff and solid waste of disused cars)

Considering a climate-constrained future to maintain global temperatures by carbon abatement, there is increasing consensus that continued reliance of oil is not sustainable (Chauvet et al., 2012; Glynn et al., 2014; Newman et al., 2009; Sovacool, 2007). Hence the case for energy transition is increasingly supported. Even the previously optimistic International Energy Agency is now promoting policies to deal with declining output and to promote alternative sources of energy to satisfy future mobility and economic needs (International Energy Agency, 2013, 2012, 2005). It is likely that oil prices will be more volatile and this has wide ranging implications on cardependent societies and transportation systems. Transport energy transition by promoting alternative fuel has been proposed to phase out oil, but progress remains slow overall despite various national efforts to promote public transport projects and alternative energy for cars (Rotmans et al., 2001; Solomon and Krishna, 2011). There is strong inertia in continued oil use due to vested interests, ranging from century long investments in oil-related infrastructure and technology. From oil production (oil-wells), oil transport (pipelines, tankers) to oil consumption (automobiles) there are many contributions to path dependency (Cherp et al., 2011; Geels, 2011). Depending on global oil supply, the cost of retrofitting the world's transport system is gigantic and will take many decades, given oil-based infrastructure and equipment are durable and expensive. Excepting rail based modes, oil is likely to retain its dominance in most motorised transportation, in particular automobiles, shipping and aviation, because alternative fuels are still under many technological and infrastructural restrictions and are not developed in a scale that could replace oil to meet the world's mobility and economic needs in the short term (Browne et al., 2012; Hall and Day, 2009). For instance, widespread use of electric vehicles will impose greater load on power generation and grid capacity and are struggling to overcome battery costs and operational constraints. Meanwhile substitution liquid fuels, such as biofuels, could not be produced at a quantity that could replace petroleum fuels economically. Unless efficient and large scale algae fuel production becomes commercially and ecologically viable, the ethical and 
environmental concerns of growing crops for biofuel remain valid due to substantial use of already scarce water resources and arable land (Hira and de Oliveira, 2009; Slade and Bauen, 2013). Apart from energy supply concerns and at an urban planning context, policy makers tend to focus on equipment and fleet (for instance, alternative fuel vehicles) but are not addressing the root of the problem, in the form of oil consumptive urban form and infrastructure (Jaccard et al., 1997). Besides at a household level, vehicle ownership can be seen as investment. If oil price regained high levels, or fluctuates greatly, increased ownership in oil-dependent assets where energy supply is uncertain could mean widespread ineffective investment in the society. The same also applies for excessive road investment at an urban level. Therefore, oil dependent urban forms present significant risks.

In the recent years of higher oil prices, the concept of oil vulnerability emerged as a future-looking concept to deal with the dual challenge of peak oil and climate change. However it is likely energy prices would become increasingly uncertain or unpredictable. Future energy shock events, such as war fought over oil and constrained oil supply could realistically happen. The extent on how the urban and transportation system could cope with such shocks is not well understood. Traditional transport modelling is not particularly effective in taking account of energy. Most technical assessments of transport systems are not well equipped to deal with the issue of petroleum risk. Travel models have traditionally been estimated from cross-sectional household survey data of the car-based past. The resulting lack of variation in fuel prices with observed travel behaviour has generally precluded the incorporation of fuel prices as a variable, especially for the context of Australia (Evans et al., 2007). In Australia, a number of toll road projects were found over-estimating future demand, partly high oil prices in that period had not been factored in (Davidson, 2011; Harvey et al., 2011). This experience casts doubt on the conventional transport modelling in predicting actual demand due to the impacts of high or uncertain oil prices. Some of the money that may be spent on underused car infrastructure would have been better spent in other ways. For western countries, 'denial and delay' remain the main policy settings as car-control policies tend to be politically unattractive. Energy shortage and climate change is often thought as less of a concern compared to job growth and the economy during elections. Public knowledge about such complex issues is worryingly lacking as illustrated by a prevailing businessas-usual approach by many decision makers at all levels: from international organisations, countries, local governments, businesses and households (de Almeida and Silva, 2011). Meanwhile for the less democratic city states like Hong Kong or Singapore, transport policy is less affected by voter intentions due to different government arrangements. A technocratic approach in Hong Kong allowed strong pro-rail and anti-car policy and this helped the city to build extensive railways. However the level of oil vulnerability in Asian cities remains unexamined. New research is needed to identify if and how Asian cities are less oil vulnerable, and in what way, compared to more car-dependent cities. This can offer policy insights to urban and transport planners to better oil-proof these cities.

There is scant research on comparative international experiences of oil vulnerability. Previous research is predominantly Anglo-spherical. Nevertheless motorisation is rapid in Chinese and South East Asian developing cities, and most of these cities rely on imported oil. To this end, this study aims to create a methodology to extend oil vulnerability to Asian cities with the use of commonly available indicators, across jurisdictions. This should help contribute to the international understanding of car dependence and the quality of urban transport systems. Stakeholders (e.g.: policy makers, governments, industries and communities) may use this method for not only identifying oil vulnerable areas, but also devising better urban transport policies and equitable provision of transport infrastructure. Oil vulnerability mapping is a particularly powerful tool to identify areas that require urgent attention and intervention (Preston et al., 2011; Reid et al., 2009). The impact of Dodson and Sipe's (2008, 2007; 2013) research, which spurred Australian government attention on oil vulnerability, demonstrates the value of mapping based research. With a specific focus on Asia Pacific and energy related issues, the new proposed method also focused on spatial variation of oil vulnerability variables. This helps fill the gaps of Newman and Kenworthy's $(1999 ; 1989)$ research on car dependence and oil that used comparative study of aggregated urban data alone.

This paper is organised as follows. A literature review is used to further explain the concept of oil vulnerability and to develop a conceptual framework for this research. The scope of the paper and the justification for the choice of Brisbane and Hong Kong is then provided. The methods are outlined, including the choice of variables for analysis. The results are then provided, with discussion of the patterns of oil vulnerability identified in the two cities, 
both by sub-region and in mapping outputs. The paper concludes with a reflection on limitations and on future research options.

\section{Literature Review}

Urban research on oil use and car dependence began after the 1970s Oil Crises. Focusing on Australia, Newman et al. (1985) used mode share and travel distance to estimate spatial variation of energy consumption and monetary cost. The debate back the 1980s was whether easing congestion could help reduce fuel consumption, which justifies the construction of metropolitan highway networks. The issue of the lack of direct per capita energy data was a justification for the use of proxy measures in their study. Later the same researchers began a series of global compilations of transport indicators, including car dependence and energy use indicators and suggested strong correlation of higher density and lower car dependence (Kenworthy and Laube, 2001; Kenworthy et al., 1999; Newman and Kenworthy, 1989). The attention to energy by transport scholars waned during the 1990s, perhaps due to a worldwide oil glut with relatively stable and low oil prices until the 2000s. Since then oil prices began to be more volatile, with fuel protests worldwide prior to the recent collapse in prices. This rapid skyrocketing and instability of oil price was widely believed to be attributed to growth in rapidly industrialising nations, in particular China and India, driving up oil demand (Skeer and Wang, 2007) and also due to speculation of oil futures with imperfect information in the market (Ederington et al., 2011; Labban, 2010). In this period, urban scholarship saw renewed urban interest in oil prices. Dodson and Sipe (2005) from Australia appeared one of the first to use the term "oil vulnerability". A series of indices were created to describe socioeconomic impacts of increasing oil price on households in relation to transport. By indexing a number of oil vulnerable indicators and mapping them, they found that outer suburban areas were significantly more oil vulnerable than inner city areas, given they tend to be car dependent and poorly serviced by public transport, and with lower socio-economic conditions and higher relative mortgage debt (Dodson and Sipe, 2008). Public and academic attention to oil vulnerability in Australia prompted government response at all levels (Australian Senate, 2007; Brisbane City Council, 2007; Queensland Government, 2007). Mapping oil vulnerability from census data has since been used in Canada (Akbari and Nurul Habib, 2014; Arico, 2007), Melbourne (Fishman and Brennan, 2009), South-East Queensland (Runting et al., 2011) and in the US (Sipe and Dodson, 2013). Advanced simulation techniques have been employed in more recent studies in the UK and New Zealand (Lovelace and Philips, 2014; Rendall et al., 2014). However these studies has not been conducted in Asia.

There remain research gaps on the relationship of oil vulnerability factors and transport infrastructure, in particular a lack of a clear conceptual framework for oil vulnerability studies, unlike more mature vulnerability fields such as climate change (Choy et al., 2013; Janssen et al., 2006; Measham et al., 2011), disaster management (Birkmann, 2007; Cardona, 2007) and development aid (Alwang et al., 2001; Chambers, 1989; Watts and Bohle, 1993). The concepts from these prevailing accepted frameworks of vulnerability could provide useful guidance in conceptualising oil vulnerability variables. In view that oil vulnerability research at the urban level has not been fully defined before, and without any preceding guidance, a commonly used framework by the Intergovernmental Panel on Climate Change (2001) is adapted as a framework for further oil vulnerability research. Oil vulnerability is therefore defined in this research as 'the degree to which a system is susceptible to, or unable to cope with, adverse effects of oil price variability and extremes'. Three major components are proposed for oil vulnerability as represented graphically in Figure 2:

- Exposure (E) represents to what extent energy related events are able to affect the system. It is usually measured by oil consumption variables, such as car ownership or distance of travel.

- $\quad$ Sensitivity (S) represents the degree to which a system is affected by both energy and non-energy drivers. It is often measured by social variables, such as income or socio-economic wellbeing. 
- Adaptive capacity (AC) represents to the ability of a system to change in a way that makes it better equipped to manage its future exposure and/or sensitivity to oil price influences. Adaptive capacity can be short term or long term and can include capacity for substituting mobility for other means of communication.

These components has been used in previous oil vulnerability studies but have not been stated explicitly. Exposure (usage of oil consumptive modes) and sensitivity (income levels, disadvantage or house ownership pressures) have been widely included in previous research efforts. However, adaptive capacity has not been adequately included in most previous studies. Public transport access was considered by Runting et al.'s (2011) research, using a 1 kilometre Euclidian buffer to public transport stops, and with no consideration of service quality. Active transport was considered by Rendall et al.'s (2014) method to estimate the ability to use active travel to reach activity destinations (e.g.: shops and services) but this requires intensive computing methods and good quality activity location datasets.

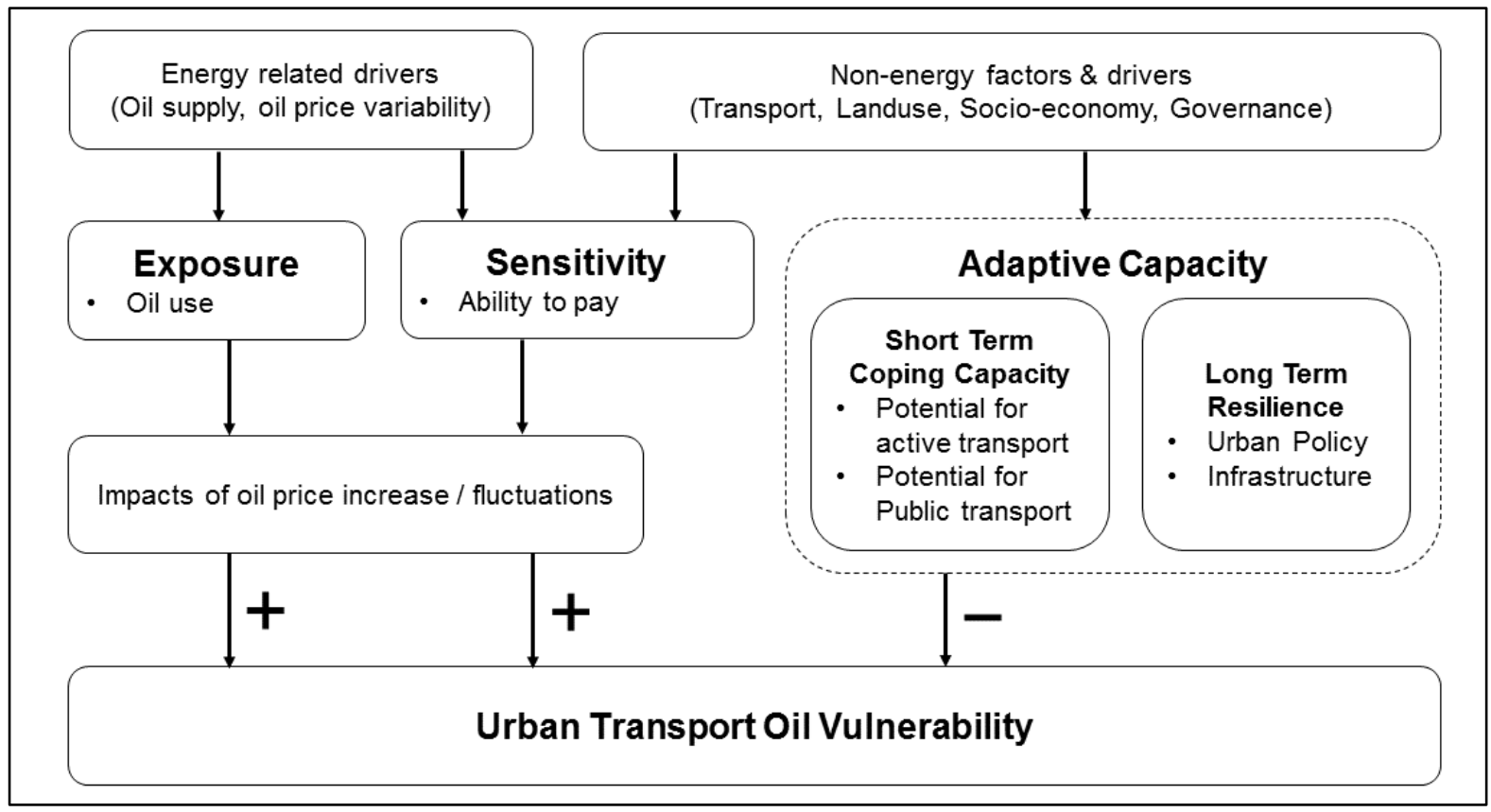

Figure 2: A proposed framework for future oil vulnerability research (Adapted from Marshall et al. (2010))

\section{Scope of Study}

This study aims to expand oil vulnerability mapping to international comparisons, using variables that are closely related to oil-related transport costs in urban areas. The chief rationale is that non-urban areas should not be considered within the scope of research due to lack of critical mass for public transport provision and hence should be treated differently. Definitions of 'urban area' differ, ranging from population size, density, administrative or political boundaries or economic function (Cohen, 2006). In a transport study context, Newman and Kenworthy's $(1999 ; 1989$ a) international city comparison study defined urban area as "large, fairly contiguous built up area". In more recent studies, with better improvements in geographic datasets, Mees (2009) was able to 'reconstruct' urban areas based on smaller census tracts to allow more accurate interurban comparisons. This study adapts the same approach by selecting Asian Pacific cities that have available "block level" datasets comparable across jurisdictions. The urban areas of Hong Kong and Brisbane are chosen as two cases for international comparison because of comparable data availability at fine grained census level. The two cities provide a contrasting example of how a city with low oil vulnerability might look like using previously tested mapping methods, as compared to a more car- 
dependent city. Both cities have experienced similar fluctuations in petrol price (Figure 3), despite the level of fuel tax in Hong Kong being much higher than in Brisbane. In 2014, Hong Kong's average unleaded petrol price was at US average unleaded petrol price was at US\$2.06 compared to Australia's US\$1.23 (German Society for International Cooperation, 2015).

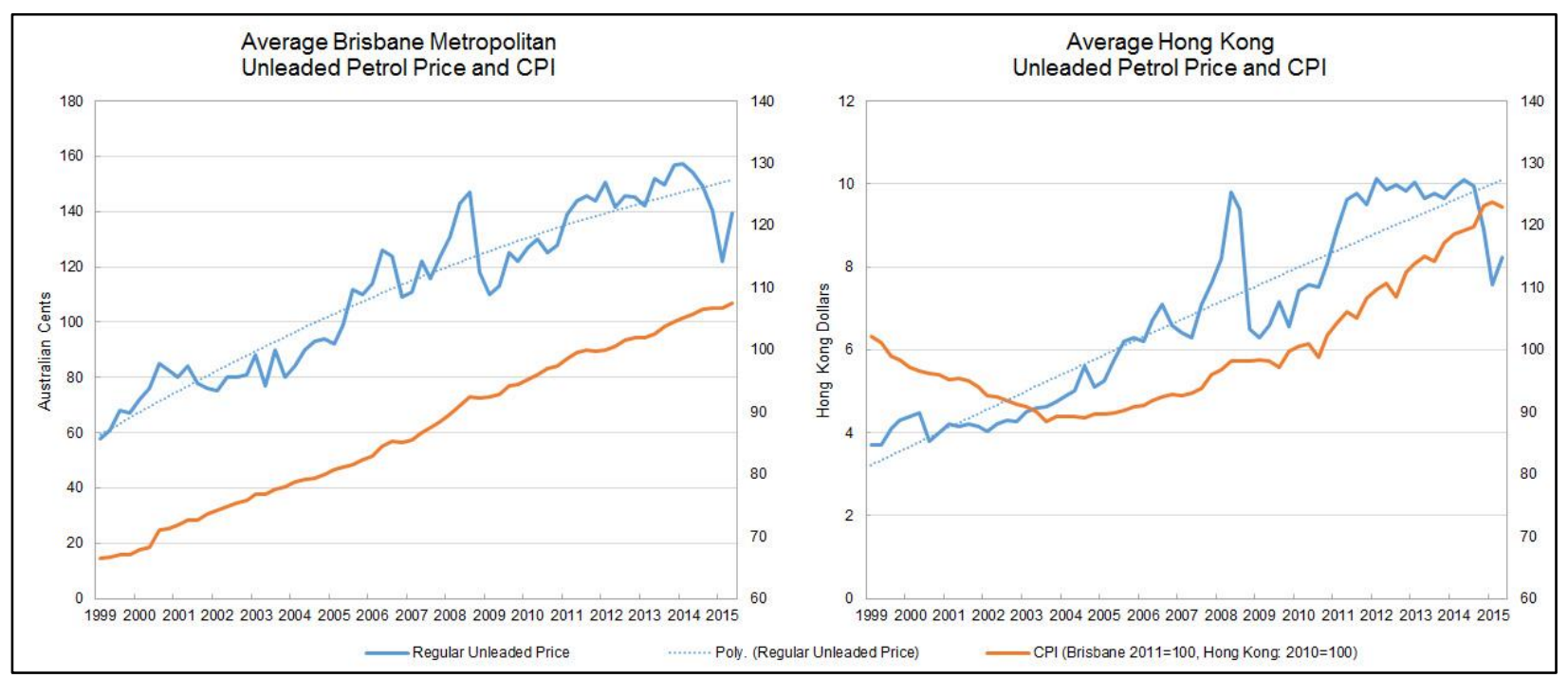

Figure 3: Average fuel price of Brisbane and Hong Kong, 1999 to 2015

(Hong Kong Consumer Council, 2015; Queensland Government Statistician's Office, 2015)

The other similarities and differences of the two selected study cities are outlined in Table 2. Both Hong Kong and Brisbane are former British colonies, founded at a similar time. The institutions and governance exhibit certain similarities and there is no language barrier in obtaining and analysing the datasets. To allow intercity comparison, this study will compare all urban census blocks of the two cities together. This approach differs to previous oil vulnerability city studies as the indicators were only comparing local census blocks within the same city (Dodson and Sipe, 2008, 2007). Considerable emphasis is put on ensuring measurements that could be made direct comparisons that were not possible in previous oil vulnerability studies. Simple metrics are preferred over detailed but more complicated ones as it is easier to obtain reliable, commonly-available data between the two cities. Australia adapts a lower-limit for an area to be considered as urban character known as the "Linge criteria", which has an advantage of objectivity and consistency (Australian Bureau of Statistics, 2011; Linge, 1965). This criteria is applied to both cities census blocks for delimiting urban extent:

- have a population density greater or equal to 100 persons per sq. $\mathrm{km}$ and a dwelling density greater or equal to 50 dwellings per sq $\mathrm{km}$; or

- have a population density greater or equal to 200 person per sq. $\mathrm{km}$.

Figure 4 shows the urban extent of the study areas based on this criteria. Large urban area blocks with no significant resdient population, such as airports, heavy industrial facilities, ports are excluded. Like many major cities, both Brisbane and Hong Kong have neighbouring cities bordering them. For the case of Brisbane, the urban area extends to the entire South East Queensland (SEQ) region from Gold Coast to the South to Noosa in the North. Pleasant weather and interstate "sea-change" migration have helped SEQ's population growth. Commonly, the Greater Brisbane area includes a large swathes of peri-urban area to north of Redcliffe are falling within ABS's urban definition. For allowing better comparision the Hong Kong, that part is excluded in this study. Hong Kong borders the Special Economic Zone of Shenzhen and forms part of the Pearl River Delta in the Guangdong province - an industrial powerhouse and a fast growing megacity region. However, as a Special Administrative Region, Hong Kong operates a different customs and taxation arrangement with Mainland China. Visas are required for entering 
the respective borders and there is no free flow of labour. However commuting for jobs or education across borders is increasing due to increased economic activity across the Hong Kong-Shenzhen border.

Table 2. Key Urban Characteristics of Greater Brisbane and Hong Kong

\begin{tabular}{|c|c|c|}
\hline Differences & Greater Brisbane & Hong Kong \\
\hline Total Population (2011) & $2,003,499$ & $7,070,388$ \\
\hline Urbanised Population (2011) & $1,930,767$ & $7,053,701$ \\
\hline Total Area & $5904 \mathrm{~km}^{2}$ & $1,104 \mathrm{~km}^{2}$ \\
\hline Private vehicle per 1000 & 613.40 & 50.08 \\
\hline $\begin{array}{l}\text { Mode share of low occupancy } \\
\text { vehicles (private cars) }\end{array}$ & $93.09 \%$ & $28.07 \%$ \\
\hline Transport energy use per person & 31.6 gigajoule & 6.5 gigajoule \\
\hline Urban form and density & Dispersed and low & Compact and high \\
\hline Society and Culture & $\begin{array}{l}\text { Western and mainly white but ethnically } \\
\text { multicultural due to sustained global } \\
\text { immigration }\end{array}$ & $\begin{array}{l}\text { Chinese based, ethnically homogenous but with } \\
\text { strong British and Western influences. English } \\
\text { widely used as business and official language }\end{array}$ \\
\hline Development expansion space & $\begin{array}{l}\text { With room for further expansion but } \\
\text { controlled by regional planning }\end{array}$ & $\begin{array}{l}\text { Constrained by natural geography with limited } \\
\text { room to expand. Future large scale development } \\
\text { most likely by sea reclamation or redevelopment } \\
\text { of existing urban areas }\end{array}$ \\
\hline Planning Governance & $\begin{array}{l}4 \text { local councils (Brisbane, Logan, Redlands } \\
\text { and Moreton Bay) with strong Queensland } \\
\text { State Government involvement under the } \\
\text { Southeast Queensland Regional plan }\end{array}$ & $\begin{array}{l}\text { Hong Kong Special Administrative Region } \\
\text { Government as a quasi-city state. Increasing } \\
\text { cooperation with national PRC government. }\end{array}$ \\
\hline Borders & No border controls to neighbouring areas & $\begin{array}{l}\text { Border and immigration controls along Hong } \\
\text { Kong-China border }\end{array}$ \\
\hline Similarities & Greater Brisbane & Hong Kong \\
\hline Natural Geography & $\begin{array}{l}\text { Coastal city separated by Brisbane River, } \\
\text { some outlying islands but largely } \\
\text { undeveloped }\end{array}$ & $\begin{array}{l}\text { Coastal city separated by a wider Victoria } \\
\text { Harbour, numerous outlying islands, some highly } \\
\text { populated and connected by bridges or tunnels }\end{array}$ \\
\hline Built-up Area (\%) & $840 \mathrm{~km}^{2}(14.2 \%)$ & $264 \mathrm{~km}^{2}(14.9 \%)$ \\
\hline Average per-capita income: & US $\$ 47,124$ & US\$55,167 \\
\hline $\begin{array}{l}\text { British Colonial Settlement } \\
\text { since }\end{array}$ & 1825 & 1842 (ended 1997) \\
\hline Human Development Index & 0.933 (very high) & 0.891 (very high) \\
\hline Motorised transport modes & Bus, Rail, Ferry, Car & Bus, Rail, Ferry, Tram/Light-Rail, Car \\
\hline
\end{tabular}

(Source: Australian Bureau of Statistics, Hong Kong Census and Statistics Department, Brisbane City Council, Hong Kong Transport Department, UITP Millennium Cities Database for Sustainable Transport, United Nations)

This paper attempts to examine passenger transport only. The main rationale is that the potential reduction of passenger transport is easier to achieve than freight transport - by organising trips collectively in public transport or reduction of trips by telecommuting. Another consideration is a practical one, as urban freight is still not as adequately understood as passenger transport and data is not widely available. The examination of oil vulnerability of freight transport will be useful for future research but is beyond the scope of this analysis 


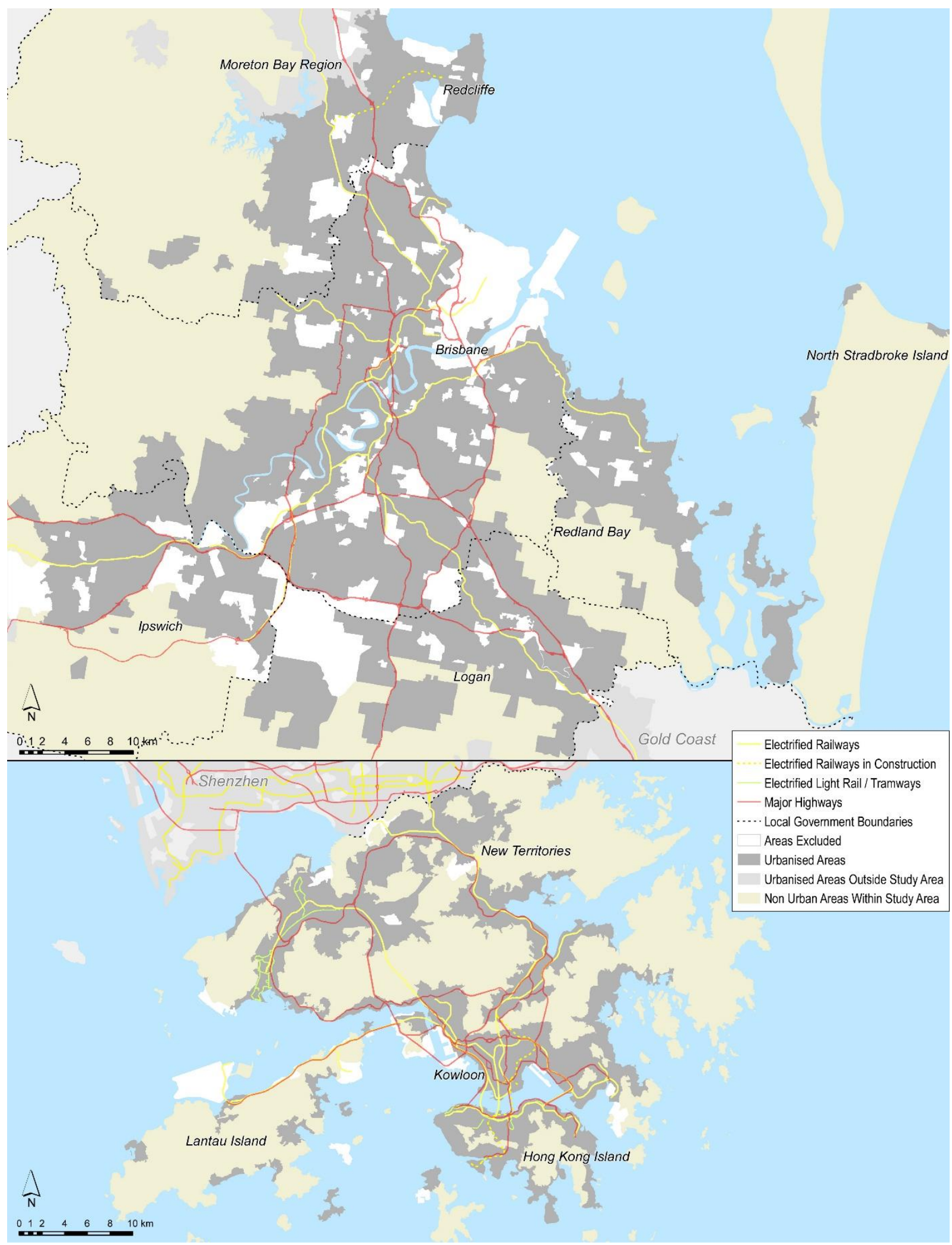

Figure 4: Urban Extent and Transport Features of Brisbane (top) and Hong Kong (bottom) 


\section{Methodology}

A number of commonly available urban and transport variables are chosen to reveal and visualise oil vulnerability. Table 3 lists the data oil vulnerable variables and the rationale for their inclusion. Each component is further explained regarding the justifications of inclusion based on previous literature and considerations during the course of this research.

Table 3 Oil Vulnerability Components and the Variables Used

\begin{tabular}{|c|l|l|}
\hline $\begin{array}{c}\text { Vulnerability } \\
\text { Component }\end{array}$ & \multicolumn{1}{|c|}{ Variable } & \multicolumn{1}{|c|}{ Rationale } \\
\hline \multirow{2}{*}{ Exposure } & $\begin{array}{l}\text { E1) Proportion of the use of low occupancy vehicles as a } \\
\text { mode to work }\end{array}$ & $\begin{array}{l}\text { To estimate oil consumption of a necessary trip } \\
\text { and a proxy of low occupancy vehicle ownership }\end{array}$ \\
\cline { 2 - 3 } & E2) Estimated average commuting distance & $\begin{array}{l}\text { To estimate oil consumption of a necessary trip } \\
\text { and a proxy to vehicle distance travelled }\end{array}$ \\
\hline \multirow{2}{*}{ Sensitivity } & S1) Proportion of households with low income \\
Capacity & $\begin{array}{l}\text { AC1) Proportion of area within 400m of public transport } \\
\text { stop ranked by level of service in weekdays (see Table 3) }\end{array}$ & $\begin{array}{l}\text { To estimate the inability to pay for increased } \\
\text { transport costs due to higher oil prices }\end{array}$ \\
\cline { 2 - 4 } & $\begin{array}{l}\text { AC2 ) Percentage of area within 400m buffer of electric } \\
\text { public transport stops (For this case. railways and tramways, } \\
\text { includes stops under construction) }\end{array}$ & $\begin{array}{l}\text { To estimate the ability to use non-oil based } \\
\text { transport }\end{array}$ \\
\hline
\end{tabular}

\subsection{Exposure $(E)$}

This component measures the risk exposure to increasing oil prices. Variables selected for this component are largely similar to those used in the "Vulnerability index for petroleum energy rises" (VIPER) method by Dodson and Sipe (2007). The mode share of low occupancy vehicles (LOV) to work is the main variable for determined car use and hence oil consumption. Car ownership has been previously considered in most Western oil vulnerability studies. However, this variable is not included in Hong Kong's census questionnaire. While an estimated car ownership data is available in the Hong Kong Transport Department's Household Travel Survey, it is not detailed enough to compare with Australian census data. Instead, the journey to work (JTW) flow weighted-average commuting distance based on JTW matrices of the 2011 Censuses of Hong Kong and Australia is used for estimating actual oil use in transport. An area's average distance is the summation of each JTW flows from an origin to destinations then multiplied with the respective network distance to destinations. The JTW data is only available at a district level census block (SA2 in Australia and District Council Constituency Areas in Hong Kong). The shape of this census geography level is directly overlayed to other smaller blocks for an approximation of commuting distance value. While this may have issues of modifiable areal unit problem, this is the only comparative data available for this study. To reflect commuting to areas adjacent to the study cities, especially at the periphery, the commuting flows to the surrounding areas are included. For Brisbane this includes the whole of SEQ and for Hong Kong includes trips to other parts of China (mainly Shenzhen and Macau).

\subsection{Sensitivity $(S)$}

For other prevailing oil vulnerably studies, income levels were chosen as a sensitivity measure. However it is not easy to compare income directly due to constant fluctuations of currency exchange and varying purchasing power. This study uses a relative measure of inability to pay, hence the percentage of low income households was chosen as the sensitivity variable. The cut-off low income level was set at HK\$10,000 monthly and AU $\$ 400$ weekly, which is approximately US\$321 and US\$427 weekly at 2011 exchange rates. This difference averages out the higher income/price levels in Australia when compared to Hong Kong. Using this cut-off, the mean value of low income household percentage is around $8 \%$ for both cities with a similar frequency distribution. The main aim of this 
approach was allow identification of spatial variation of those less able to pay for future impacts. Testing with other income cut-offs exhibited similar spatial patterns. Figure 5 shows the spatial patterns of the Exposure and Sensitivity variables in both cities.

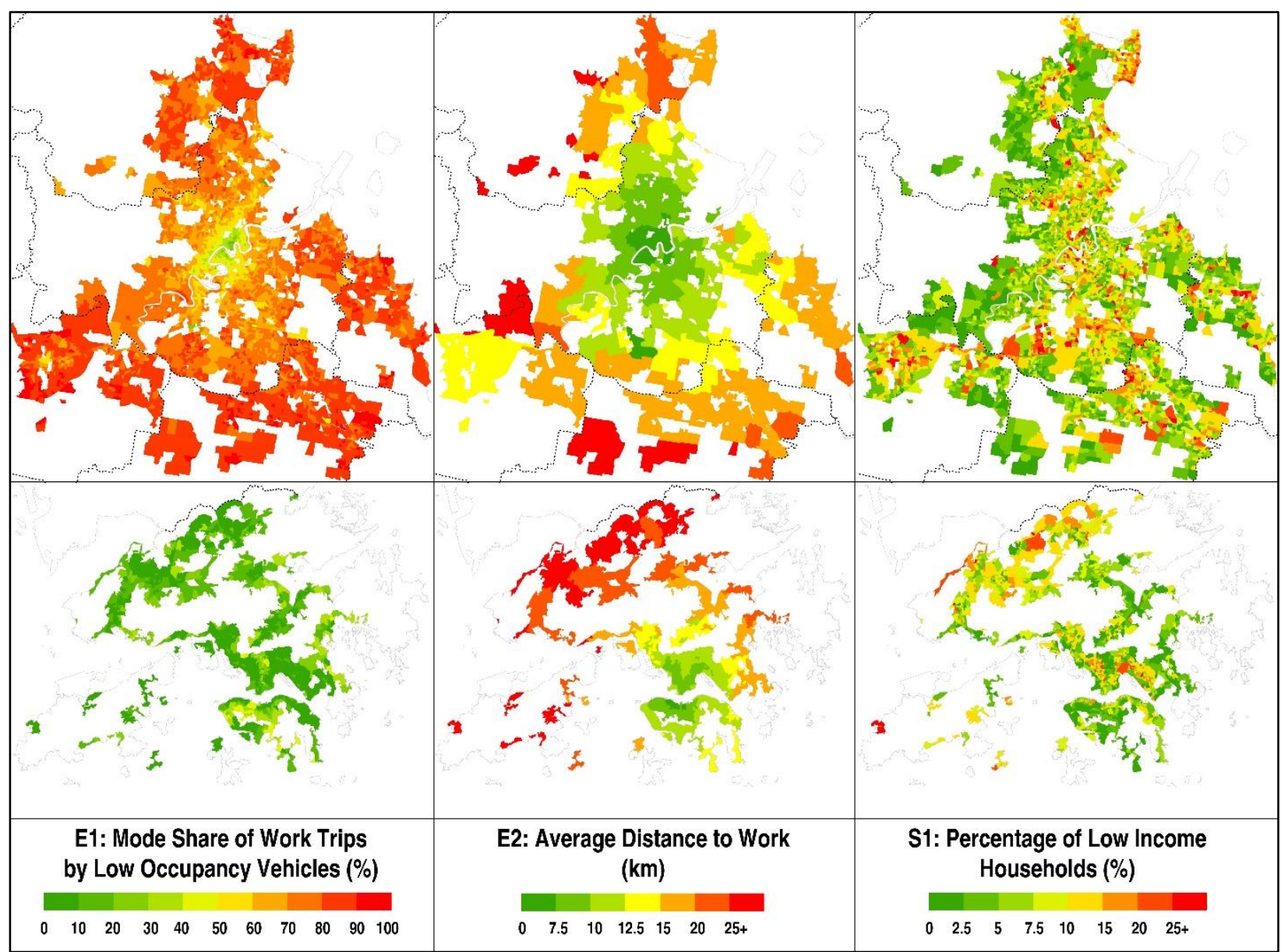

Figure 5: Potential Impact of Oil Prices: Exposure and Sensitive Variables in Brisbane (top) and Hong Kong (bottom)

\subsection{Adaptive Capacity (AC)}

Runting et al.'s (2011) study included a simple buffer of public transport stops with $1 \mathrm{~km}$ distance buffer which is a crude measure of public transport service and accessibility. With increasing proliferation of public transport data and GIS analytical capacities, it is possible to estimate public transport service level by its frequency and span (Keller 2012, Antrim and Barbeau 2013). Detailed route and stop data was obtained from the Hong Kong Transport Department and Translink, the public transport authority for SEQ. The 16-seat public light buses (PLB) played an auxiliary role in Hong Kong. These flexible PLB cover areas not served by franchise buses and are able to stop in any areas except restricted curbs. However inclusion of PLB is not possible due to the lack of stop data.

Using the common features of public transport available in the two cities, a simple yet robust method to estimate public transport level of service (PTLOS) index is designed for this study. The following equations are used for this index:

$$
\text { PTLOS }=\text { Average Frequency } \times \text { Effective Span of Service } \times \text { Days of Service }
$$


Average Frequency $=\frac{\text { Peak Frequency Value } \times \text { Off Peak Frequency }}{2}$

Effective Span of Service $=$ Hours of Service of each day

(Note: services with frequency less than 2 hours are not regarded as a regular service)

The estimation of public transport frequency are based on a scoring system in Table 4.

Table 4: Public transport level of service (PTLOS) scores for variable AC1 (Adapted from Pitot et al. (2006))

\begin{tabular}{|c|c|}
\hline Frequency (minutes) & PTLOS Score \\
\hline less than 5 & 6 \\
\hline 10 & 5 \\
\hline 15 & 4 \\
\hline 30 & 3 \\
\hline 60 & 2 \\
\hline more than 60 & 1 \\
\hline
\end{tabular}

It is possible to view this value in two ways: 1) summation for an estimated total routes passing a stop in a day regardless of needing transfer to reach final destination and 2) the best level of service for the stops along a route without transfer and is more attractive to users. A composite index of the two values is used which reflects the level of service of public transport by span and frequency and provides a city-wide measure of public transport availability. The routes are assigned with a PTLOS value, then it is extended to their associated stops as shown in Figure 6. Then by using the Network Analysis tools provided in ArcGIS, the walkability to each stop is estimated by applying a walkway pedestrian shed analysis. The threshold of 400 metres is used, which is a widely adapted standard used in various jurisdictions as a reasonable distance for accessing public transport by foot (Daniels and Mulley, 2013). The percentage of area covered by the PTLOS Score is assigned to each census block to form variable $\mathrm{AC} 1$. While this method does not measure the monetary and time cost from actual origin and destinations, it is an adequate measure for this research for a general estimation of whether an area is covered by usable public transport service which provides mobility without the use of car (Walker 2012). In addition, to reflect the fact that electrified rail based transport are the only widely used modes that are entirely oil free, a measure of 400 metres buffer from electrified railway stops is included as variable AC2.

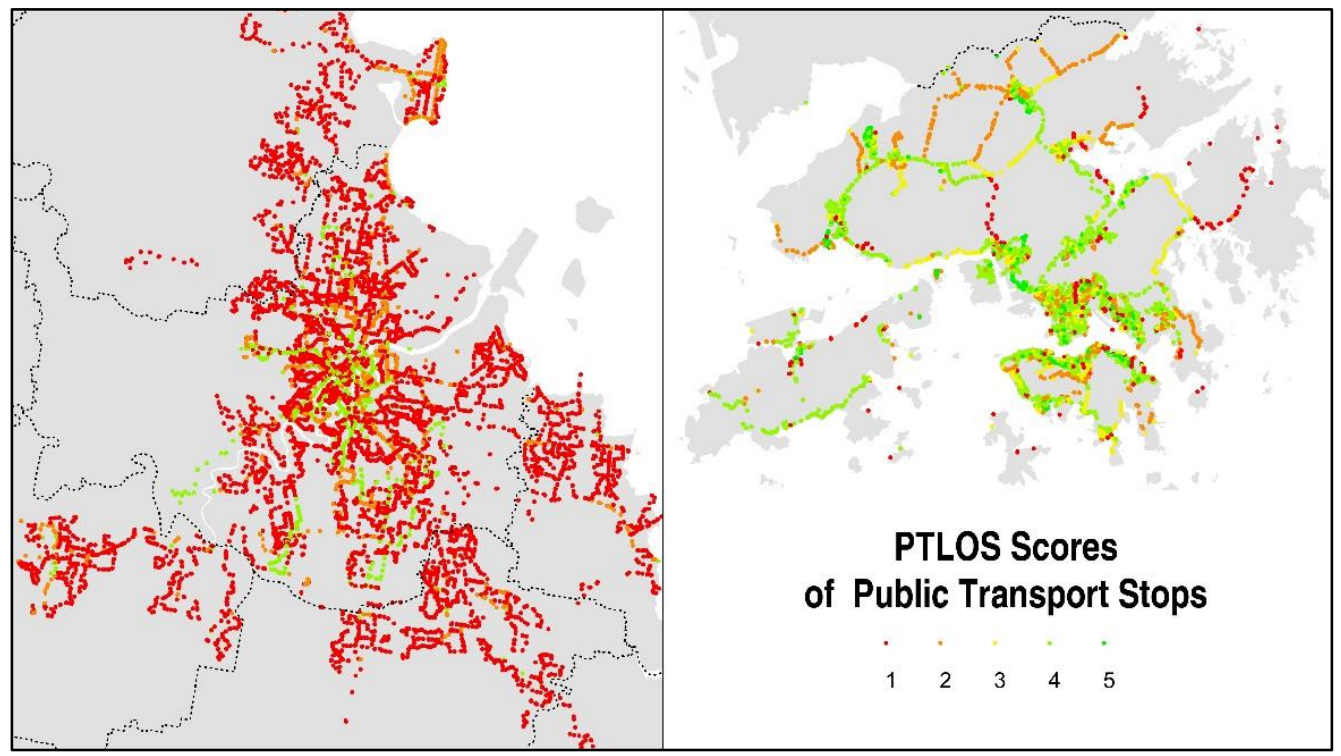

Figure 6: The estimated PTLOS score for each transport stops within the urban extent of Brisbane (left) and Hong Kong (right) 


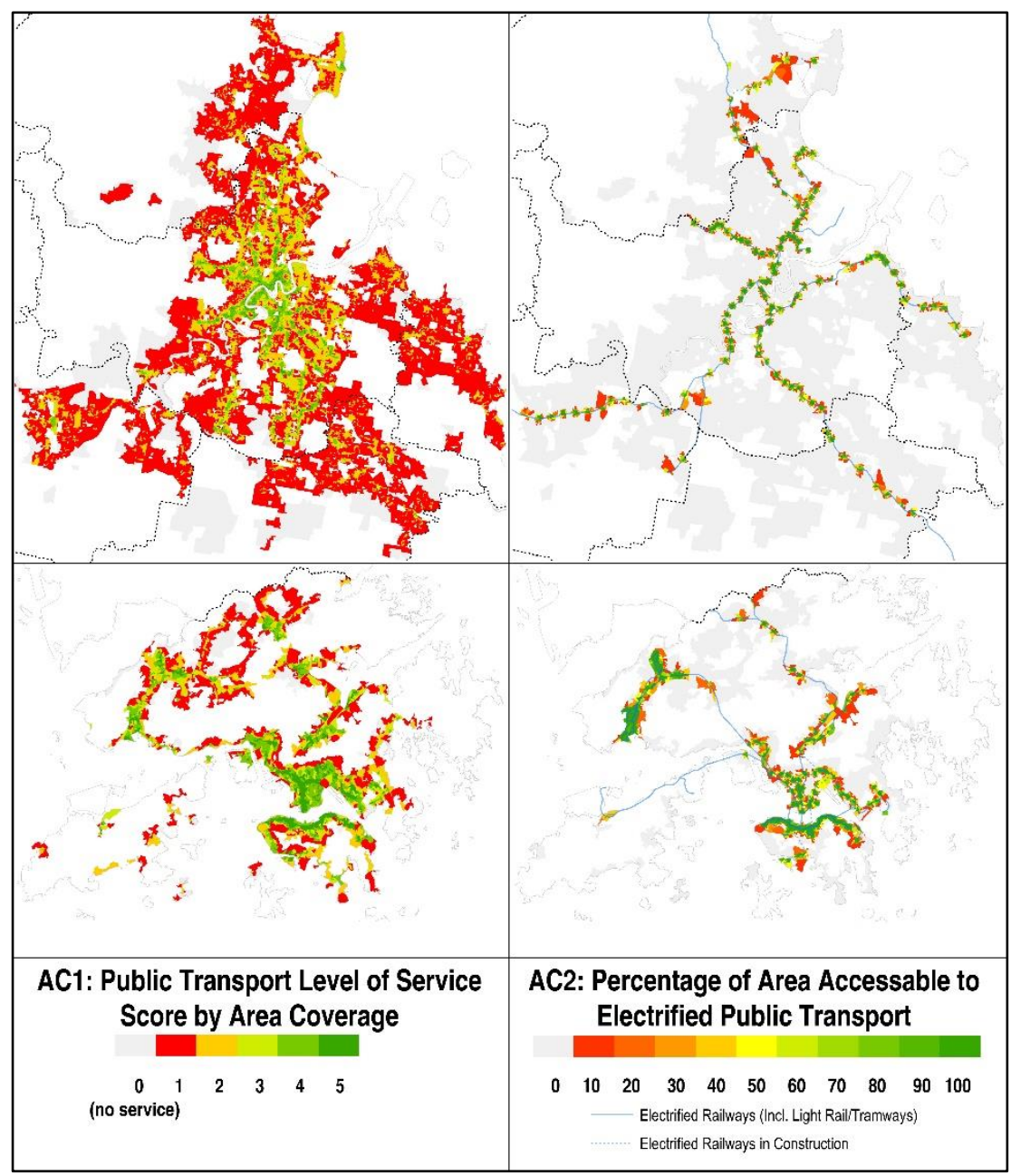

Figure 7: Adaptive Capacity Variables of Brisbane (top) and Hong Kong (bottom)

\subsection{Summary of the Variables and Composite Oil Vulnerability (OV) Measure}

The local area variation in mean values is shown in Table 5. Hong Kong stands out with very low levels of LOV mode share to work, higher levels of public transport service and non-oil transport infrastructure availability when compared to Brisbane. The overall commuting distance and prevalence of low income is similar for both cities. The values of commuting distance across Brisbane is more evenly spread whereas it is more variable in Hong Kong.

The exposure, sensitivity and adaptive capacity variables are mean adjusted by converting into z-scores (standard deviation values) for which 0 is the mean value. The use of standard deviation z-scores and composite aggregation of vulnerability components are also used in other vulnerability assessments such as in terms of climate change and social vulnerablity (Cutter et al. 2003). The advantage of this approach is the spatial variance of each component can be better preserved. Also it can be directly computed into a component vulnerability score using the equation:

$$
V=E+S-A C
$$


Table 5: Descriptive statistics (mean values) of oil vulnerability variables by the areas of Hong Kong and Brisbane

\begin{tabular}{|c|c|c|c|c|c|}
\hline Area & $\begin{array}{c}E 1 \\
\text { To work by } \\
\text { LOV } \\
\% \\
\end{array}$ & $\begin{array}{c}E 2 \\
\begin{array}{c}\text { Avg. Commute } \\
\text { Distance } \\
(\mathbf{k m})\end{array} \\
\end{array}$ & $\begin{array}{c}S 1 \\
\text { Low } \\
\text { Income } \\
\% \\
\end{array}$ & $\begin{array}{c}A C 1 \\
\text { Level of Service of } \\
\text { Public Transport } \\
\text { (Score) } \\
\end{array}$ & $\begin{array}{c}A C 2 \\
\text { Area with Electrified } \\
\text { Public Transport } \\
\% \\
\end{array}$ \\
\hline Hong Kong SAR & 10.23 & 13.42 & 7.6 & 3.17 & 76.92 \\
\hline Hong Kong Island & 13.12 & 9.71 & 5.95 & 3.83 & 89.27 \\
\hline Kowloon & 6.58 & 9.81 & 9.03 & 4.00 & 73.01 \\
\hline New Territories (excl. Lantau) & 11.56 & 20.43 & 8.33 & 2.23 & 66.63 \\
\hline Lantau & 3.6 & 24.51 & 14.17 & 0.88 & 22.18 \\
\hline Greater Brisbane & 71.95 & 14.36 & 8.9 & 1.23 & 61.60 \\
\hline Brisbane & 66.35 & 10.69 & 9.44 & 1.62 & 64.19 \\
\hline Ipswich & 82.65 & 16.56 & 9.99 & 0.68 & 51.01 \\
\hline Logan & 85.54 & 17.74 & 10.96 & 0.64 & 53.89 \\
\hline Moreton Bay & 78.99 & 17.09 & 9.02 & 0.83 & 49.45 \\
\hline Redland Bay & 72.44 & 17.19 & 13.05 & 0.52 & 54.83 \\
\hline
\end{tabular}

\section{Results and Discussion}

\subsection{Patterns of Oil Vulnerability in the two cities}

The population share of the values of each level for the broad areas of both cities are shown in Figure 8. Figure 9 maps the spatial distribution of the composite oil vulnerability z-score values by standard deviation breaks of -2.5 to 2.5 with intervals of 1 .

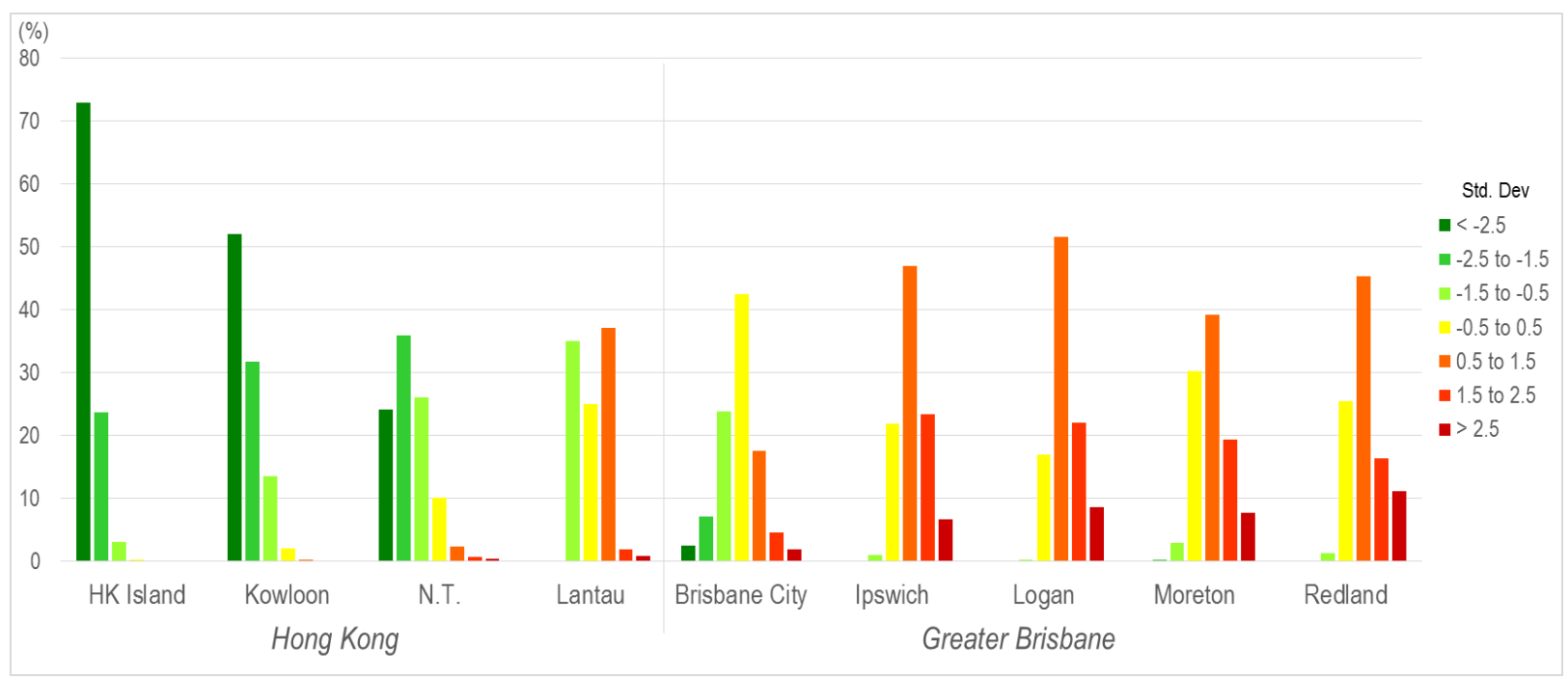

Figure 8: Comparison of the Percentage of Population of Oil Vulnerability Levels across the Study Area 


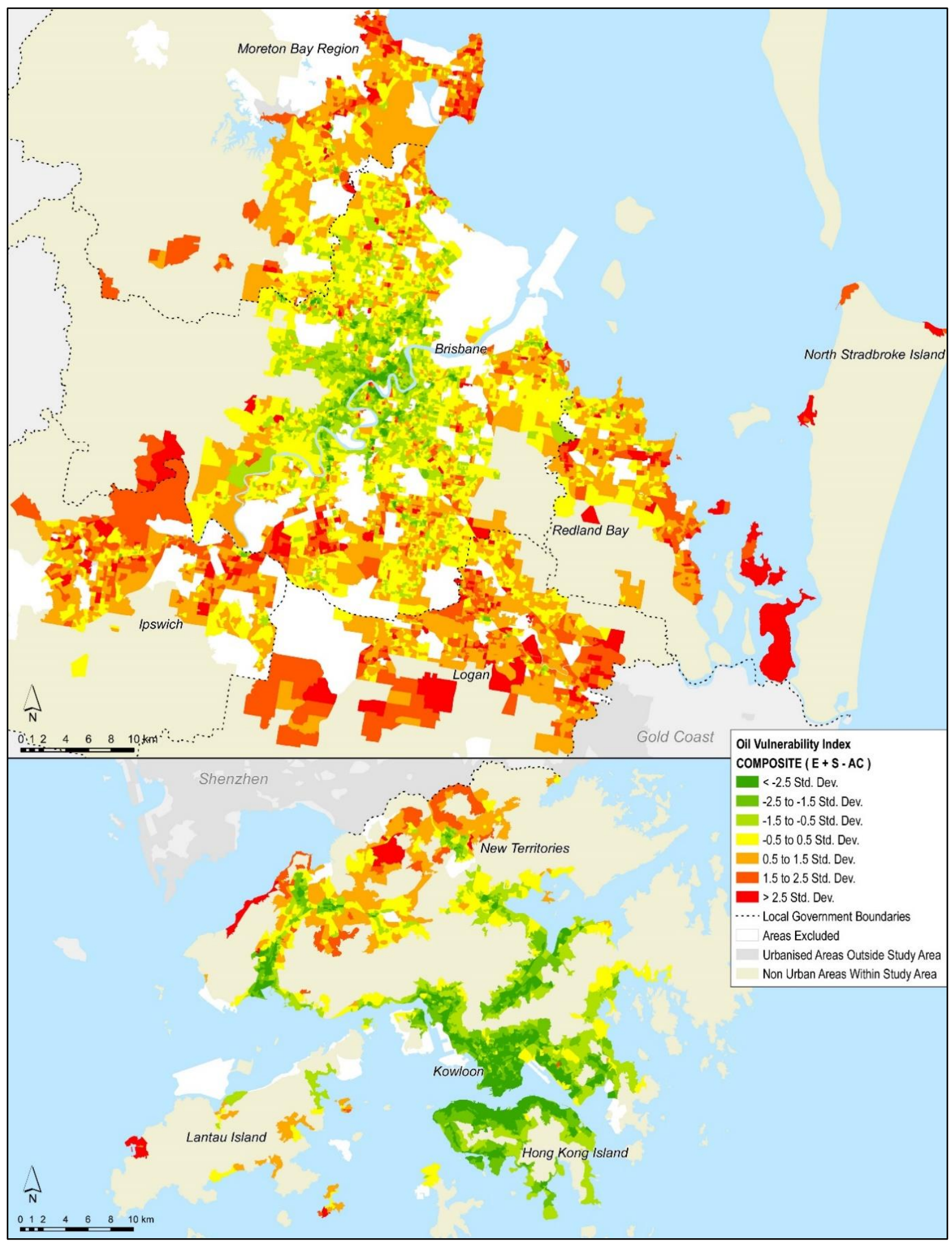

Figure 9: Composite Oil Vulnerability Index of Brisbane (top) and Hong Kong (bottom) 
Advancing from previous studies (Dodson and Sipe 2007, Runting et al. 2011) the figures provide more detailed analysis and allow direct comparison across the two cities. The maps and population analysis of composite oil vulnerability is able to reflect the spatial variation of higher car dependence, commuting distance, low income areas and public transport service. Overall Hong Kong's oil vulnerability pattern is quite different to Brisbane's. Overall, oil vulnerability is much less across all its regions, except perhaps Lantau. The mapping shows nuanced patterns largely based on the central-peripheral arrangement of both cites. Yet Hong Kong's outer new towns (e.g.: Tuen Mun, Yuen Long, North District and Tai Po) are adequately served by heavy rail or light rail. Despite longer average commuting distance in these outlying areas, most transport passenger tasks are mostly carried by energy efficient and oil-free rail transport with the exception of Lantau Island and other outlying islands. These islands also rely on ferry transport which is also oil vulnerable. This study did not examine ferry transport thoroughly but it had attracted some local concerns in Hong Kong due to high oil prices and increase in ferry fares (Hong Kong Legislative Council, 2015). For Brisbane outer urban development is mainly facilitated by highways with railway played a limited role. The rail frequency is often only at 30 minutes, while Hong Kong is able to provide metro-style services with frequency less than 10 minutes and even less than 3 minutes at peak hours on some lines. Geographically, it should be noted that Hong Kong and Brisbane are both separated by water features. Yet Hong Kong already has three cross-harbour rail links between Hong Kong Island and Kowloon, namely Tsuen Wan Line (opened 1980), Tseung Kwan O Line (opened 1989) and Tung Chung Line (opened 1998). An additional crossing, the Shatin to Central link is currently under construction and expect to open in 2020. The Tung Chung Line also connects the urban core to Lantau Island and the Airport. Brisbane's rail network is shaped radially but with only one railway crossing - the Merivale Bridge (opened 1979) across Brisbane River. This creates a bottleneck severely restricting the ability to run trains with higher frequency. A Cross River Rail project has been proposed but it not yet designed or funded. In Brisbane a sizeable network of busways has also been constructed (Tanko and Burke, 2013). In terms of fuel, the Brisbane City Council have adopted a policy of purchasing only compressed natural gas (CNG) buses and currently the bus fleet is almost half running on CNG. However natural gas prices are still subject to oil price fluctuations as natural gas is substitutionally in nature to oil as an energy commodity.

\subsection{Energy Transition and Future Transport Plans of Brisbane and Hong Kong}

The exposure and sensitivity to oil vulnerability used in this study are based on 2011 census data. Recently developments in alternative fuels offer a promising solution for reducing oil use. Future oil vulnerability studies will have to consider this latest development but it will be difficult due to lack of car fuel-mix data. The avoid-shiftimprove approach has been recognised as an effective way to reduce oil use simultaneously (Dalkmann and Brannigan, 2007; Schipper and Marie-Lilliu, 1999). For the avoid-approach, reducing oil use by controlling car dependence not only helps address oil vulnerability, the benefits also include improving air quality, saving valuable urban land from car park provisions, and creating opportunity for physical activity. This is achieved in part by high fuel taxes and parking restrictions in Hong Kong (Barter, 2014; German Society for International Cooperation, 2015). Transport and land use planning based on non-oil public transport is also imperative to reduce oil vulnerability. Both Hong Kong and Brisbane's peripheral areas as seen to be more oil vulnerability characterised with higher car use, and lower socio-economic status. But low adaptive capacity could be improved by widespread provision of public transport. There is a strong case to make public transport more competitive and attractive given active transport has only a short range. Public transport need not be expensive and costly. Improved transit networks that maximise existing fleet can reduce oil vulnerability further, particularly in Brisbane (Mees and Dodson, 2011).

Gilbert and Perl's (2007) argument for electricity grid-connected rail to address oil vulnerability is supported by the results. Figure 9 shows that both cities have reduced oil vulnerability in areas close to rail line. Hong Kong's plans to further to pursue a rail-based investment, as indicated in the latest Railway Development Strategy 2014, will be beneficial. Whilst the SEQ 2031 Transport Plan indicates further expansion of railway infrastructure across SEQ but funding is highly uncertain (Queensland Government, 2011). Brisbane is likely to remain oil vulnerable for some time to come. 


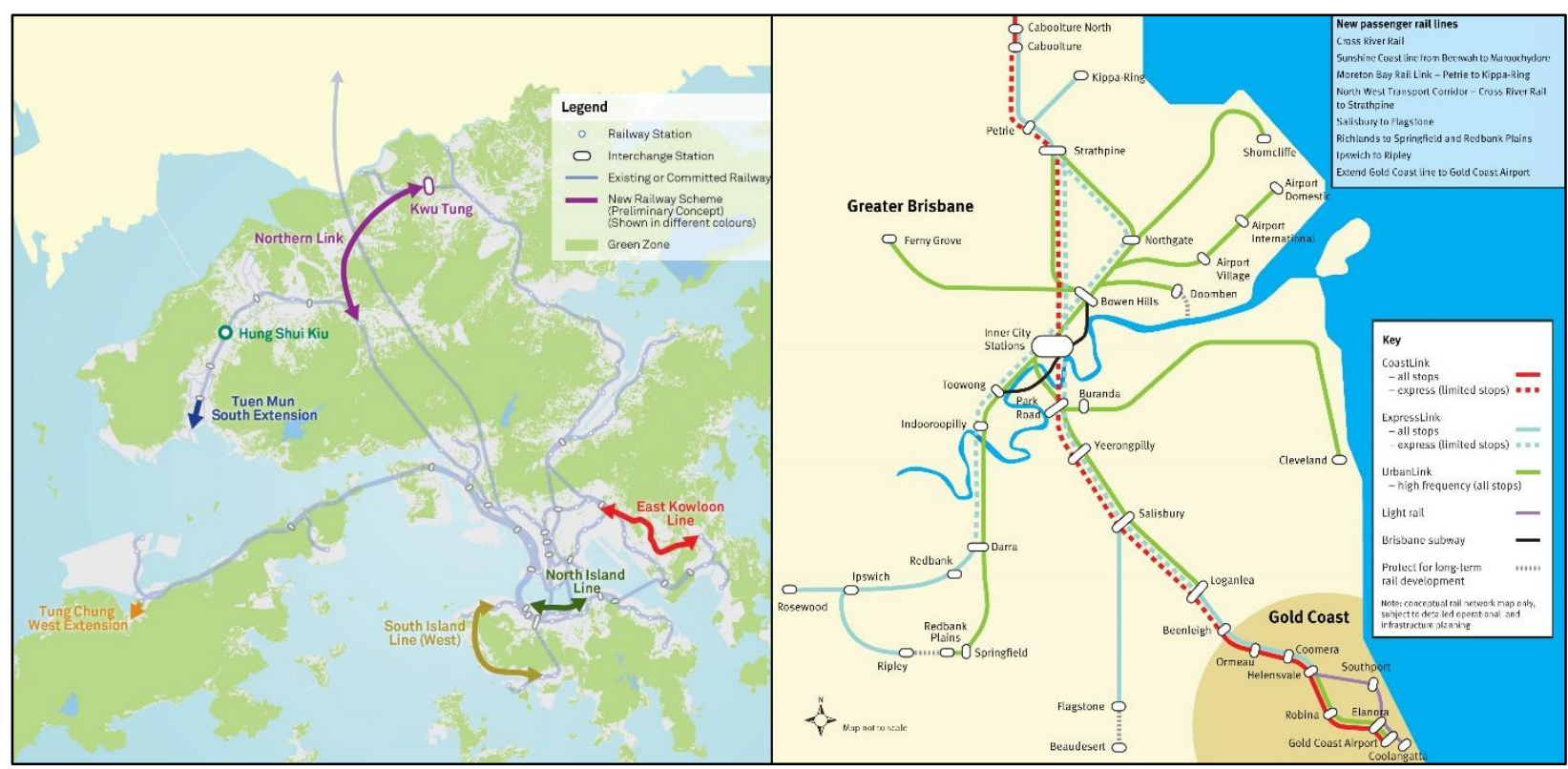

Figure 10: Indicative Rail Development Plans of Hong Kong and Brisbane for 2031 (Source: Hong Kong Transport and Housing Bureau, 2014; Queensland Government, 2011)

\section{Conclusion}

This research brings oil vulnerability to the Asia region for the first time. By developing common metrics, delimiting urban extend and the use of small census blocks the paper shows that comparative oil vulnerability mapping across quite different urban contexts is achievable. This approach could be further expanded to other cities, in particular the Asia Pacific region. Improvements to previous oil vulnerability research and further conceptualisations of exposure, sensitivity and adaptive capacity in oil vulnerability studies could help identify the impacts of oil supply and price fluctuations in transport and land use systems. Oil vulnerability indices are useful as an approach to warn policy makers to expedite action, however, further research on verification of actual transport energy use and cost statistics is necessary to provide empirical evidence of the relationship of oil vulnerability assessment and actual oil use statistics. Statistical tools such as regression modelling can be used to correlate other census statistics with observed travel behaviour. Household travel surveys may be used in conjunction with other census statistics to develop models to further interrogate the socio-economic determinants of oil vulnerability.

\section{References}

Akbari, S., Nurul Habib, K., 2014. Oil vulnerability in the greater Toronto area: impacts of high fuel prices on urban form and environment. Int. J. Environ. Sci. Technol. 11, 2347-2358. doi:10.1007/s13762-014-0641-9

Alwang, J., Siegel, P., Jorgensen, S., 2001. Vulnerability: a view from different disciplines.

Arico, R., 2007. Measuring the oil vulnerability of Canadian cities. Simon Fraser University, Master Thesis. Burnaby, BC. Simon Fraser University.

Australian Bureau of Statistics, 2011. Australian Statistical Geography Standard (ASGS): Volume 4 - Significant Urban Areas, Urban Centres and Localities, Section of State.

Australian Senate, 2007. Australia's future oil supply and alternative transport fuels: Final report. Senate Printing Unit, Canberra.

Barter, P.A., 2014. A parking policy typology for clearer thinking on parking reform. Int. J. Urban Sci. 1-21. doi:10.1080/12265934.2014.927740

Barter, P., Kenworthy, J., Laube, F., 2003. Lessons from Asia on Sustainable Urban Transport, in: Low, N.P., 
Gleeson, B.J. (Eds.), Making Urban Transport Sustainable.

Birkmann, J., 2007. Risk and vulnerability indicators at different scales: Applicability, usefulness and policy implications. Environ. Hazards 7, 20-31. doi:10.1016/j.envhaz.2007.04.002

Brisbane City Council, 2007. Climate Change and Energy Taskforce Final Report (prepared by Maunsell Australia) (No. March). Brisbane.

Browne, D., O’Mahony, M., Caulfield, B., 2012. How should barriers to alternative fuels and vehicles be classified and potential policies to promote innovative technologies be evaluated? J. Clean. Prod. 35, 140-151. doi:10.1016/j.jclepro.2012.05.019

Cardona, O.D., 2007. Indicators of disaster risk and risk management : program for Latin America and the Caribbean: summary report. Inter-American Development Bank, Sustainable Development Department, Washington DC, USA.

Chambers, R., 1989. Vulnerability, coping and policy. IDS Bull. 20, 33-40.

Chauvet, M., Selody, J.G., Laxton, D., Kumhof, M., Benes, J., Kamenik, O., Mursula, S., 2012. The Future of Oil: Geology Versus Technology, IMF Working Papers. doi:10.5089/9781475503302.001

Cherp, A., Jewell, J., Goldthau, A., 2011. Governing Global Energy: Systems, Transitions, Complexity. Glob. Policy 2, 75-88. doi:10.1111/j.1758-5899.2010.00059.x

Choy, D.L., Clarke, P., Jones, D., Serrao-Neumann, S., Hales, R., Koschade, O., 2013. Understanding coastal urban and peri-urban Indigenous people's vulnerability and adaptive capacity to climate change.

Cullinane, S., 2003. Hong Kong's low car dependence: lessons and prospects. J. Transp. Geogr. 11, 25-35. doi:10.1016/S0966-6923(02)00042-X

Dalkmann, H., Brannigan, C., 2007. Module 5e Transport and Climate Change, in: GIZ Sourcebook for DecisionMakers in Developing Cities.

Daniels, R., Mulley, C., 2013. Explaining walking distance to public transport: The dominance of public transport supply. J. Transp. Land Use 6, 5. doi:10.5198/jtlu.v6i2.308

Davidson, P., 2011. Modelling toll roads - where have we gone wrong ?, in: Australasian Transport Research Forum 2011.

de Almeida, P., Silva, P.D., 2011. Timing and future consequences of the peak of oil production. Futures 43, 10441055. doi:10.1016/j.futures.2011.07.004

Dodson, J., Sipe, N., 2008. Shocking the Suburbs: Urban Location, Homeownership and Oil Vulnerability in the Australian City. Hous. Stud. 23, 377-401. doi:10.1080/02673030802015619

Dodson, J., Sipe, N., 2007. Oil Vulnerability in the Australian City: Assessing Socioeconomic Risks from Higher Urban Fuel Prices. Urban Stud. 44, 37-62. doi:10.1080/00420980601023810

Dodson, J., Sipe, N., 2005. Oil Vulnerability in the Australian City. Urban Research Program, Griffith University, Brisbane.

Ederington, L.H., Linn, S.C., May, A.D., Fernando, C.S., Lee, T.K., 2011. Factors Influencing Oil Prices : A Survey of the Current State of Knowledge in the Context of the 2007-08 Oil Price Volatility.

Evans, R., Burke, M., Dodson, J., 2007. Clothing the Emperor ?: Transport modelling and decision-making in Australian cities 106-107.

Fishman, E., Brennan, T., 2009. Oil vulnerability in Melbourne. Institute for Sensible Transport.

Geels, F.W., 2011. The multi-level perspective on sustainability transitions: Responses to seven criticisms. Environ. Innov. Soc. Transit. 1, 24-40. doi:10.1016/j.eist.2011.02.002

German Society for International Cooperation, 2015. International Fuel Prices 2014. Eschborn, Germany.

Gilbert, R., Perl, A., 2012. Transport Revolutions: Moving People and Freight Without Oil, 2nd ed. Earthscan, London.

Gilbert, R., Perl, A., 2007. Grid-connected vehicles as the core of future land-based transport systems. Energy Policy 35, 3053-3060. doi:10.1016/j.enpol.2006.11.002

Glynn, J., Chiodi, A., Gargiulo, M., Deane, J.P., Bazilian, M., Gallachóir, B.Ó., 2014. Energy Security Analysis: The case of constrained oil supply for Ireland. Energy Policy 66, 312-325. doi:10.1016/j.enpol.2013.11.043

Hall, C. a. S., Day, J.W., 2009. Revisiting the Limits to Growth After Peak Oil. Am. Sci. 97, 230-237. doi:10.1511/2009.78.230

Han, S.-Y., Seo, Y.-W., 2010. International Comparative Analysis for Energy Efficiency of Transport Sectors in OECD Countries - Using Energy Intensity Method and Malmquist Approach. 
Harvey, M., Lu, W., Louis, P., 2011. Review of traffic forecasting performance - toll roads.

Hira, A., de Oliveira, L.G., 2009. No substitute for oil? How Brazil developed its ethanol industry. Energy Policy 37, 2450-2456. doi:10.1016/j.enpol.2009.02.037

Hong Kong Consumer Council, 2015. Oil Price Data Archive [WWW Document]. URL http://www.consumer.org.hk/pricewatch/oilwatch/ (accessed 9.28.15).

Hong Kong Legislative Council, 2015. LCQ14: Reply by Secretary for the Environment regarding an queston by a LegCo member on oil price [WWW Document]. URL http://www.info.gov.hk/gia/general/201501/28/P201501280460.htm

Hong Kong Transport and Housing Bureau, 2014. Railway Development Strategy 2014.

Intergovernmental Panel on Climate Change, 2001. Climate Change 2001: Synthesis Report. Geneva, Switzerland. International Energy Agency, 2013. World Energy Outlook 2013. IEA Publishing, Paris, France.

International Energy Agency, 2012. Energy Technology Perspectives 2012.

International Energy Agency, 2009. World Energy Outlook 2009.

International Energy Agency, 2005. Saving oil in a hurry. IEA Publishing, Paris, France.

Jaccard, M., Failing, L., Berry, T., 1997. From equipment to infrastructure : community energy management and greenhouse gas emission reduction 25, 1065-1074.

Janssen, M. a., Schoon, M.L., Ke, W., Börner, K., 2006. Scholarly networks on resilience, vulnerability and adaptation within the human dimensions of global environmental change. Glob. Environ. Change 16, 240252. doi:10.1016/j.gloenvcha.2006.04.001

Kenworthy, J., Laube, F., 2001. UITP Millennium Cities Database for Sustainable Transport. s, International Union [Association] of Public Transport [UITP], Brussels.

Kenworthy, J.R., Laube, F.B., Newman, P., Barter, P.A., 1999. An International Sourcebook of Automobile Dependence in Cities 1960-1990. University Press of Colarado, Boulder.

Labban, M., 2010. Oil in parallax: Scarcity, markets, and the financialization of accumulation. Geoforum 41, 541552. doi:10.1016/j.geoforum.2009.12.002

Linge, G.J.R., 1965. The delimitation of urban boundaries for statistical purposes with special reference to Australia : a report to the Commonwealth Statisticia. Dept. of Geography, Australian National University.

Lovelace, R., Philips, I., 2014. The "oil vulnerability" of commuter patterns: A case study from Yorkshire and the Humber, UK. Geoforum 51, 169-182. doi:10.1016/j.geoforum.2013.11.005

Marcotullio, P.J., 2003. Globalisation, Urban Form and Environmental Conditions in Asia-Pacific Cities 40, 219 247. doi: $10.1080 / 0042098032000040134$

Marshall, N., Marshall, P., Tamelander, J., 2010. A Framework for Social Adaptation to Climate Change: Sustaining Tropical Coastal Communitites and Industries.

Measham, T.G., Preston, B.L., Smith, T.F., Brooke, C., Gorddard, R., Withycombe, G., Morrison, C., 2011. Adapting to climate change through local municipal planning: Barriers and challenges. Mitig. Adapt. Strateg. Glob. Change 16, 889-909. doi:10.1007/s11027-011-9301-2

Mees, P., Dodson, J., 2011. Public Transport Network Planning in Australia: Assessing current practice in Australia's five largest cities.

Newman, P., Beatley, T., Boyer, H., 2009. Resilient Cities - Responding to Peak Oil and Climate Change. Island Press, Washington DC, USA.

Newman, P.W.G., Kenworthy, J.R., 1989. Cities and Automobile Dependence: A Sourcebook. Gower Technical, Aldershot, Hants, UK; Brookfield, VT, US.

Newman, P.W.G., Kenworthy, J.R., Lyons, T.J., 1985. Transport energy use in the Perth Metropolitan Region: Some urban policy implications. Urban Policy Res. 3, 4-15. doi:10.1080/08111148508522597

Patil, A., Herder, P., Brown, K., 2010. Investment Decision Making for Alternative Fuel Public Transport Buses: The Case of Brisbane Transport. J. Public Transp. 13, 115-133.

Pitot, M., Yigitcanlar, T., Sipe, N., Evans, R., 2006. Land Use \& Public Transport Accessibility Index (LUPTAI) Tool - The development and pilot application of LUPTAI for the Gold Coast, in: ATRF06 Forum Papers. Presented at the Australasian Transport Research Forum.

Poudenx, P., 2008. The effect of transportation policies on energy consumption and greenhouse gas emission from urban passenger transportation. Transp. Res. Part Policy Pract. 42, 901-909. doi:10.1016/j.tra.2008.01.013

Preston, B.L., Yuen, E.J., Westaway, R.M., 2011. Putting vulnerability to climate change on the map: a review of approaches, benefits, and risks. Sustain. Sci. 6, 177-202. doi:10.1007/s11625-011-0129-1 
Queensland Government, 2011. Connecting SEQ 2031 An Integrated Regional Transport Plan for South East Queensland.

Queensland Government, 2007. Queensland's Vulnerability to Rising Oil Prices Taskforce Report. Oil Vulnerability Taskforce, Brisbane.

Queensland Government Statistician's Office, 2015. Petrol: average unleaded retail price per litre, selected Queensland centres [WWW Document]. URL http://www.qgso.qld.gov.au/products/tables/petrol-avg-ulpprice-qld-centres/index.php (accessed 9.28.15).

Reid, C.E., O’Neill, M.S., Gronlund, C.J., Brines, S.J., Brown, D.G., Diez-Roux, A. V, Schwartz, J., 2009. Mapping community determinants of heat vulnerability. Environ. Health Perspect. 117, 1730-6. doi:10.1289/ehp.0900683

Rendall, S., Page, S., Krumdieck, S., 2014. Voila! A New Measure of Oil Vulnerability for Cities, in: Conference Proceedings of the 1st International E-Conference on Energies. pp. 1-22.

Rotmans, J., Kemp, R., Asselt, M. van, 2001. More evolution than revolution: transition management in public policy. foresight. doi:10.1108/14636680110803003

Runting, R., Corcoran, J., Leung, A., Pullar, D., 2011. Oil vulnerability: the effect of non-metropolitan areas and master planned estates in South East Queensland 2001-2006. Aust. Plan. 48, 117-130. doi:10.1080/07293682.2011.592501

Schipper, L., Marie-Lilliu, C., 1999. Transportation and CO2 emissions : flexing the link - a path for the World Bank, Environmental Department papers - Climate change series. World Bank.

Sipe, N., Dodson, J., 2013. Oil Vulnerability in the American City, in: Renne, J.L., Fields, B. (Eds.), Transport beyond Oil: Policy Choices for a Multimodal Future. Island Press, Washington DC, pp. 31-50. doi:10.5822/978-1-59726-242-2_3

Skeer, J., Wang, Y., 2007. China on the move: Oil price explosion? Energy Policy 35, 678-691. doi:10.1016/j.enpol.2006.01.012

Slade, R., Bauen, A., 2013. Micro-algae cultivation for biofuels: Cost, energy balance, environmental impacts and future prospects. Biomass Bioenergy 53, 29-38. doi:10.1016/j.biombioe.2012.12.019

Solomon, B.D., Krishna, K., 2011. The coming sustainable energy transition: History, strategies, and outlook. Energy Policy 39, 7422-7431. doi:10.1016/j.enpol.2011.09.009

Sovacool, B., 2007. Solving the oil independence problem: Is it possible? Energy Policy 35, 5505-5514. doi:10.1016/j.enpol.2007.06.002

Tanko, M., Burke, M., 2013. How Did Brisbane Get it's Busways ? Findings of a study into mode-choice decisionmaking in Brisbane. Presented at the Australasian Transport Research Forum, pp. 1-12.

UN Habitat, 2012. Sustainable Urban Energy - A sourcebook for Asia. Kenya.

US Energy Information Administration, 2015. What drives crude oil prices? (July, 2015). US Energy Information Administration, Washington DC, USA.

Watts, M.J., Bohle, H.G., 1993. The space of vulnerability: the causal structure of hunger and famine. Prog. Hum. Geogr. 17, 43-67. doi:10.1177/030913259301700103 